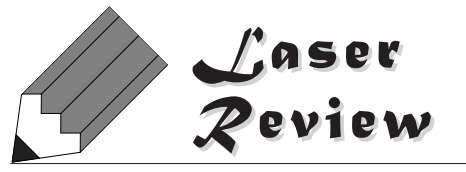

磁場下における半導体からの高強度テラヘルツ電磁波発生と応用

\author{
大竹秀幸，猿倉 信彦 \\ 分子科学研究所 ( $7444-8585$ 愛知県岡崎市明大寺町西郷中 38$)$
}

\section{Intense THz Radiation from Semiconductors in a Magnetic Field and Its Application}

\author{
Hideyuki OHTAKE and Nobuhiko SARUKURA \\ Institute for Molecular Science, 38 Nishigonaka, Myoudaiji, Okazaki, Aichi 444-8585
}

(Received February 4, 2002)

\begin{abstract}
We have generated enhanced THz-radiation from a femtosecond laser irradiating semiconductor in a magnetic field with a shallow incidence angle. The average power of THz-radiation has reached approximately $100 \mu \mathrm{W}$. Using intense $\mathrm{THz}$ radiation, a simple, noncontact, simultaneous method is applied to measure thickness and water content of black ink films independently from frequency-dependent and frequency-independent absorption characteristics of black ink films.
\end{abstract}

Key Words: THz-radiation, Magnetic field, Semiconductor, Black ink films

\section{1.はじめに}

現在, テラヘルツ領域の応用研究は急速な進歩を遂げ ている。この波長領域は電波と光の端境領域であり，今 まで適切な, 例えばレーザーのような, 光源や検出器が 少なかったため, その進歩は他の分野に比べて緩やかで あった。しかし, 近年になってフェムト秒レーザーが急 激に普及し，比較的簡単な手法を用いることにより容易 にテラヘルツ電磁波が発生できるようになったため, 様々な応用研究に用いられるようになってきている.

テラヘルッ電磁波を用いた応用研究を行う上で重要な 要素技術の一つはテラヘルツ電磁波の高強度化であっ た. 従来から用いられていた光伝導アンテナ1)から放射さ れるテラヘルッ電磁波の強度は最大でも数十マイクロ ワットであり, 分光学的には応用可能であっても工業応 用には十分とはいえなかった。工業応用を念頭に置いた 場合, 耐用性があり, 発生及び検出が容易であることが 求められる. 光伝導アンテナは過電流によりブレイクダ ウンが起こりやすく, 耐用性の面で問題となる. 検出に 関しては前出の光伝導アンテナ1) と並んでEOサンプリン グ法2)が挙げられるが, 両者とも高感度ではあるものの, 複雑な時間遅延機構を必要としているため実機配備の実 状に適していない. 従って, 時間遅延機構が必要なく, 高感度検出が可能な液体へリウム冷却型のボロメーター のような検出器が初期応用研究には最適である.しかし ながら, 実際の工業応用に際しては液体へリウムの利用 は難しく, 常温で使用できる焦電素子等で検出可能な高
強度テラヘルツ電磁波が求められていた。

そこで我々は市販の片面研磨された半導体に磁場を印 加し，フェムト秒レーザーを照射する簡便な手法によ り，高強度テラヘルッ電磁波を発生する光源を開発し た ${ }^{3-5)}$.このシステムで特筆すべき点はテラヘルツ電磁波 光源として用いた半導体が，片面だけ鏡面研磨されてい るのみで, その他は何も特殊な加工は施されていない点 である. 前出の光伝導スイッチはアンテナ構造や超格子 構造などの複雑な加工技術を必要とするが, このテラへ ルツ光源は市販の半導体を用いているので, 安定性, コ スト, 扱い易さの点で群を抜いている。本稿では磁場を 印加したInAsからの高強度テラヘルッ電磁波発生とその応 用研究に関して述べる。

\section{2. 磁場下におけるInAsからの高強度 テラヘルツ電磁波発生}

\section{$2.1 \mathrm{GaAs}$ との比較}

Fig. 1にGaAs とInAsを試料に用いたテラヘルツ電磁波の 励起強度依存性の実験結果を示す。実験配置は試料面に 対して励起光が 45 度で入射し, テラヘルツ電磁波が入射 光の反射方向に出射する配置で行った。この実験では, 試料は1.7 Tの磁場中に置かれている．励起光源はパルス 幅100フェムト秒のモード同期チタンサファイヤレーザー で, 約 $1 \mathrm{~mm}$ 程度のスポット径で試料に照射されている。 どちらの半導体もドープされていないが, InAsはその性質 上若干 $\mathrm{n}$ 型となっている。 これらの半導体は市販されてい 


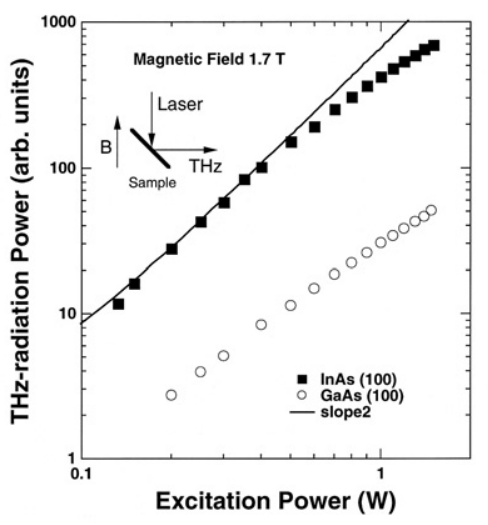

Fig. 1 Excitation power dependence of THz-radiation power for InAs (solid squares) and GaAs (open circles) at magnetic field $1.7 \mathrm{~T}$. The solid line shows slope 2 .

る片面研磨のもので，特殊な加工は何一つ施されていな い. Fig. 1から明らかなように, InAs からのテラヘルッ電 磁波強度はGaAsよりも一桁強くなっている ${ }^{3)}$. 両者のテ ラヘルッ電磁波強度の違いは伝導帯の有効質量の違いを 反映していると考えられる。点近傍でのGaAsの電子の有 効質量はInAsの有効質量の約3倍の質量をもつ. 電磁気学 的に考察すると, 外場によって駆動される電子が発生す る双極子放射の電場強度Eは電子の加速度, つまり質量の 逆数に比例すると考えられるので, InAsから放射されるテ ラヘルッ電磁波強度はGaAsからのものの抢よそ32倍の強 度をもつことになる。同様な実験配置 (Fig. 2)で試料面に 対して平行に磁場を印加した結果, 前と同様にInAsからの テラヘルッ電磁波はGaAsのものに比べて一桁大きい強度 を示した。これは前に述べた有効質量の概念を応用して 説明することができる。磁場中では, 光誘起キャリヤは 瞬時電流として流れる際にローレンツカを受け, 電流は 磁場に巻き付く方向に変調を与えられる。テラヘルッ電 磁波の放射強度は加速度の2乗に比例するが，ローレンッ 力を受けての加速の場合, 加速度は磁場強度に比例する ことになる 4,6 . すなわち, テラヘルッ電磁波の放射強度 は磁場強度の2乗に比例して強くなることになる。この場 合も，有効質量の軽いInAsの方が偏向され易いためGaAs に比べてInAsの方がより高強度のテラヘルッ電磁波を発生 させることが可能となるのである.

\subsection{InAsからの高強度テラヘルッ電磁波発生}

ここであげる実験では, 試料のInAsは最大磁場 $5.0 \mathrm{~T}$ ま で印加可能な超伝導磁石のつくる磁場内に置かれてい る. 実験配置図をFig. 2に示す。試料から放射されたテラ ヘルッ電磁波は軸外し放物面鏡で平行光線化され, 偏光 子(ワイヤーグリッド偏光子)を通り, 偏光フーリエ干渉分 光計で分光された後, 液体へリウム冷却型Siボロメーター でロックイン検波される。 (Fig. 2の (a) 光路)また, その強 度を測定する場合は分光器を通さずボロメーターに直接 テラヘルッ電磁波を導き, その強度をロックイン検波す る. Fig. 2の (b) 光路)

Fig. 2に示した配置で測定したInAsのテラヘルッ電磁波 強度の磁場強度依存性をFig. 3に示す。図中に示した，

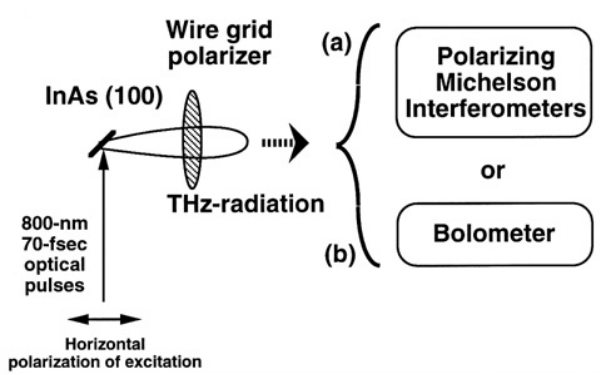

Fig. 2 Experimental setup. Path (a) and (b) are for FTIR and measurement of total radiation power.

はテラヘルツ電磁波の放射量の全量を, ○は垂直偏光 を，○は水平偏光をそれぞれ示している。（Fig.2に狲て 紙面垂直な電場ベクトルをもつ偏光を垂直偏光, 紙面面 内の電場ベクトルをもつ偏光を水平偏光と定義した。) Fig. 3から明らかなように，この実験配置では主として水 平偏光の成分が発生していることがわかる。これは表面 に垂直な双極子が放射を起こした場合，外部に放射され る電磁波が水平偏光をもつという特徵をよく表してい る. 偏光を特定しない全量検出の場合, この実験配置で はほとんど水平偏光と違いがないが, テラヘルッ電磁波 強度は抢よそ0.5 Tから $2.0 \mathrm{~T}$ 付近までの磁場強度に扔い て, 磁場強度の2乗に比例する性質を示す。しかし，テラ ヘルッ電磁波強度は 3.0 T近傍で飽和し, 3.0 T以上では激 減する.GaAsからのテラヘルッ電磁波強度が磁場強度の 2乗に比例することはZhang等により報告されていたが6), $0.2 \mathrm{~T}$ までの弱磁場での報告に留まっており, InAsからの テラヘルッ電磁波強度が磁場強度の2乗に比例してどこま で強くなるのかということはわかっていなかった。この 実験により，Fig. 3に述べた実験配置では 3.0 T近傍が高強 度テラヘルツ電磁波を得る上でもっとも効率的であると いうことが判明した4).

Fig. 4に実測されたテラヘルッ電磁波のスペクトルを示 す。拉よそ $0.3 \mathrm{THz}$ に中心持つ非常に幅広いスペクトル が得られている。スペクトル全域に渡って出現している 鋭い吸収線は, 空気中の水蒸気吸収であり, これは試料 と光路が大気中に置かれているためである。磁場誘起に よるテラヘルッ電磁波のもう一つの特徵は, 磁場の印加 強度によりスペクトル形状を制御できる点にある7). Fig. 5に示した鳥瞰図はスペクトルの磁場依存性を示してい る。便宜上, 最大強度のピークを 1 に規格化してある。 Fig. 5から明らかなように, 磁場の印加方向によらず, 磁

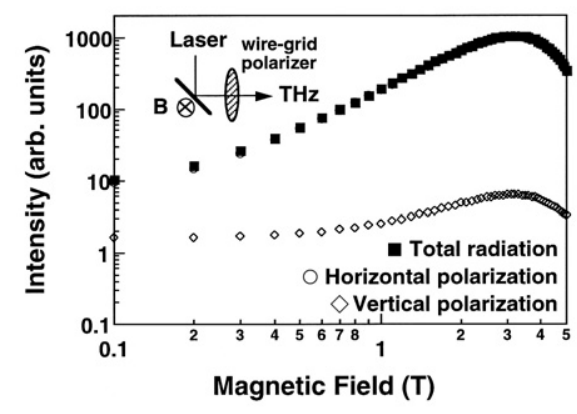

Fig. 3 Magnetic field dependence of THz radiation power. 


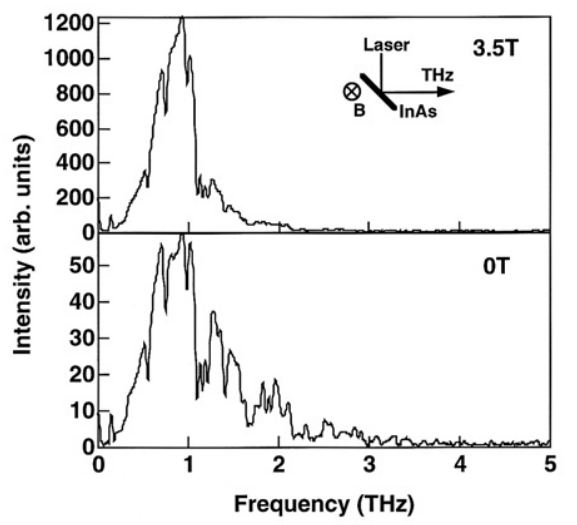

Fig. 4 Spectrum of $\mathrm{THz}$ radiation in magnetic field $3.5 \mathrm{~T}$ and $0 \mathrm{~T}$.

場強度が増すにつれてスペクトルの中心が大きく変化し ていることがわかる。

次に励起レーザー光の入射角度依存性に関して述べ る. Fig. 6に実験配置図を示した. 実験は1.7 Tの磁場中で 行った. Fig. 6に示したように励起レーザー光の入射角が $\theta$ だけ回転した際, 検出器は $2 \theta$ 回転し, 入射角 $\theta$ でのテラ ヘルツ電磁波強度を検出できる機構になっている．検出 結果がFig. 7である. Fig. 7 (a) は検出器にボロメーターの 代わりにレーザー用のパワーメーターを用いて励起レー ザー光の反射光強度を測定したものである. ○が水平偏 光，听垂直偏光を示している. 図から明らかなよう に, 水平偏光において, 入射角約 80 度のとき反射が最小 となる(ブリュースター角). Fig. 7 (b) は検出器にボロメー

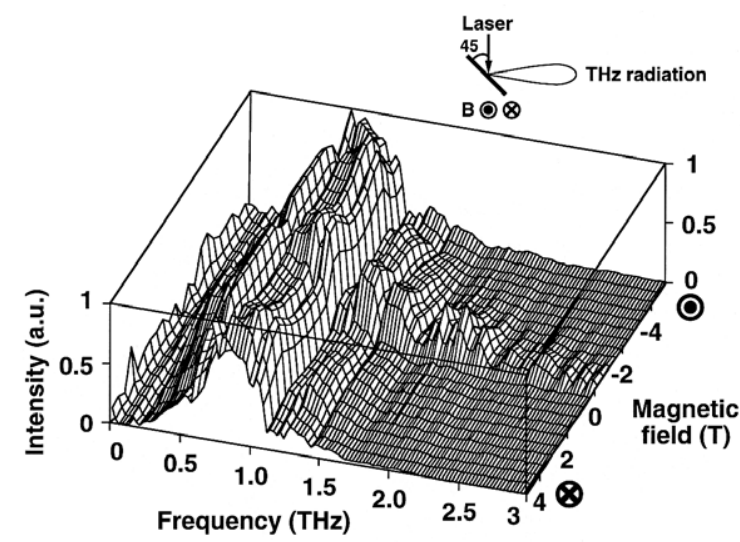

Fig. 5 3-D plot for THz-radiation spectra on different magnetic fields up to $5.0 \mathrm{~T}$.

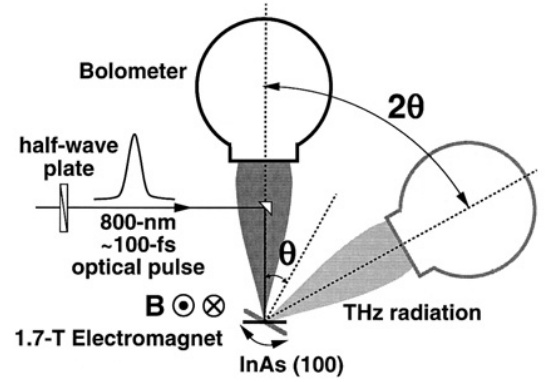

Fig. 6 Experimental setup for angular dependence of THzradiation power.
ターを用いてテラヘルツ電磁波強度を測定した結果であ る。垂直偏光は70度程度までテラヘルツ電磁波の強度に 大きな変化はなく, それ以上の角度では減衰していく. 一方, 水平偏光は入射角 40 度くらいから大きく増加し, ブリュースター角近傍で最大值をとり，その後急激に減 少していく、ブリュースター角近傍では吸収が最大にな るため, 過渡電流生成のための光励起キャリヤ数が増大 し, テラヘルツ電磁波強度が増大するものと考えられ る.ブリュースター角近傍における最大のテラヘルツ電 磁波強度は入射角 0 度のときの 5 倍, 45 度のときの 4 倍に達 し，大きな入射角で励起を行うことにより効果があるこ とを示している5). Fig.8に様々な入射角でのテラヘルツ電 磁波スペクトルを示す。入射角0度においては対称性から どちらの磁場でも同じスペクトルになっている。一方, 角度が45度，78度と大きくなるにつれて，スペクトルの 非対称性は増大していく．最大強度が得られるブリュー スター角近傍では紙面下向きの磁場配置で低周波成分が 増大していることがわかる.

\section{3 高強度テラヘルツ電磁波発生の諸条件}

高強度テラヘルツ電磁波を発生させるための条件をま
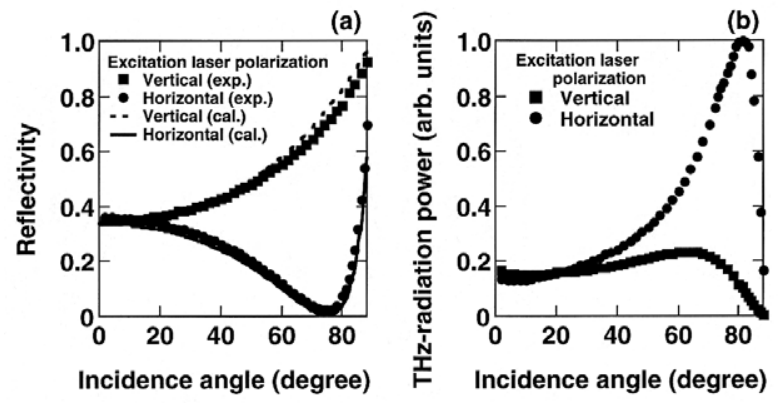

Fig. 7 Angular dependence of (a) 800-nm excitation laser reflectivity and (b) THz-radiation intensity from InAs. The solid and dotted lines indicate theoretical calculations for $\mathrm{n}=3.729, \mathrm{k}=0.448$.

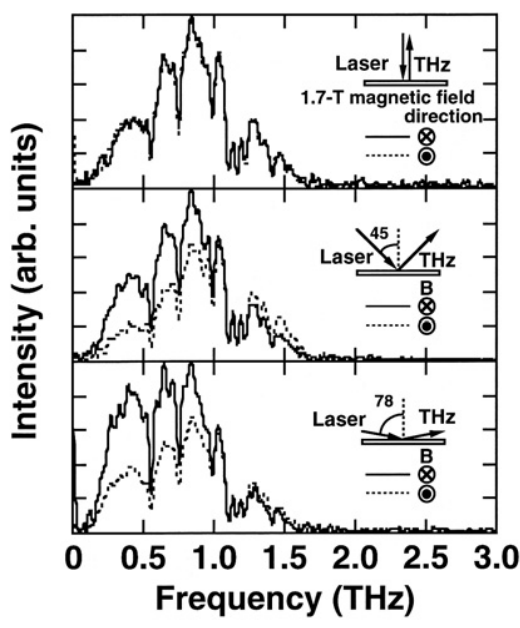

Fig. 8 THz-radiation spectra from 1.7-T magnetic field applied to an InAs emitter with 0, 45, and 78 degrees incidence angles of the excitation laser. The solid and dotted lines indicate each magnetic field direction. 
とめるとFig. 9のようになる.

(1)半導体：InAsが最も効率的である $3-5,7,8)$.

(2)印加磁場 : 3 T付近の磁場が最も効率的である4).

(3) 励起強度：より高強度で励起することが望ましい3).

(4)レーザー入射角：ブリュースター角近傍が最適であ $ろ^{5)}$.

(5)表面処理：鏡面研磨が成されていれば実用上十分な 性能を得られる ${ }^{9)}$.

(6)温度：常温で実用上十分な性能を得られる9).

上記の条件下で発生させることができるテラヘルッ電 磁波強度はおよそ100マイクロワットレベルに達してお り, 周波数領域も $0.5 \sim 2 \mathrm{THz}$ の範囲で吸収測定などの応用 研究には十分に使用可能な領域に含まれているため，テ ラヘルッ電磁波は完全に応用可能な段階に入ったといえ る10).さらに, 小型テラヘルッ電磁波発生装置の開発に も成功しており, Fig. 10に示したようにテラヘルッ電磁波 発生装置の大きさはレーザーのヘッドと $2 \mathrm{~T}$ 永久磁石を含 めて，ノートブックコンピューター程度の大きさにまで 小型化されている。このシステムは小型ながら高出力で あり，常温素子でテラヘルッ電磁波が測定できるため 様々な分野から注目を集めている11).

\section{3. 高強度テラヘルツ電磁波の応用研究}

現在までに高強度テラヘルッ電磁波を用いた応用研究 はタンパク質や超臨界状態の分光応用など多く成されて きているが，ここでは黒色インクの膜厚と水分含有量の 同時測定に関して述べる. 従来, 黒インク薄膜は可視, 近赤外領域においても不透明であるため, 可視, 近赤外 光を用いた膜厚及び水分含有量の非接触測定が困難であ り，印刷技術発展のボトルネックとなっていた ${ }^{14)}$. しか し, 我々の最近の研究から, テラヘルッ領域で黒インク が特定の吸収特性を示すことから, 膜厚等の非接触測定

\section{Laser}

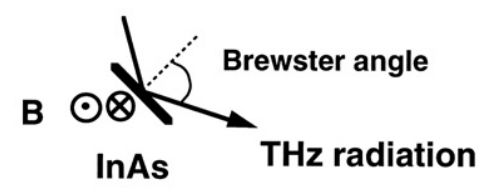

Fig. 9 Sophisticated geometrical layout to generate intense $\mathrm{THz}$ radiation.

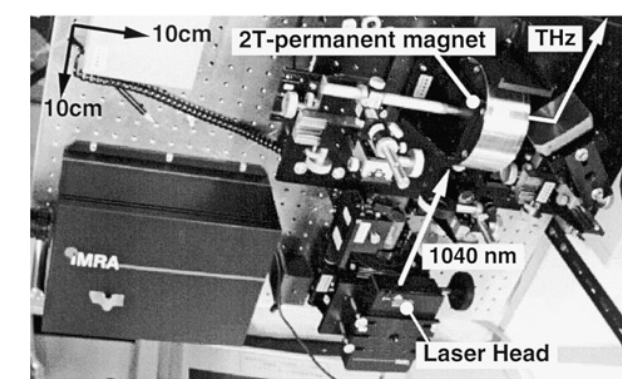

Fig. 10 Photograph of THz-radiation emitter system. Laser beam is focused onto the sample with a $2 \mathrm{~T}$ permanent magnet.
が可能となることがわかってきた。そこで透過スペクト ルから黒インク薄膜の膜厚と水分含有量を独立に測定す るシステムの開発を行った ${ }^{15)}$.

Fig. 11に実験配置図を示す７0 fsのパルス幅を有する モード同期チタンサファイヤレーザー光は常温大気中に 置かれたInAsにおよそ70度の角度で照射される，理論的に はブリュースター角近傍で励起レーザーを入射すること が望ましいが，調整が難しいため本実験では70度入射と した. InAsには1.7 Tの磁場が印加されている。テラヘル ツ電磁波は軸はずし放物面鏡でコリメートされたのち, 試料面上におよそ直径 $1 \mathrm{~mm}$ の焦点を結び, 透過光は再び 軸はずし放物面鏡でコリメートされ，偏光フーリエ干渉 分光器を通し, Geボロメーターを用いてロックイン検波 される。試料はテラヘルツ領域で透明な石英板に挟まれ ており, 試料調合時の膜厚と水分含有量を保持できる構 造になっている. Fig. 12は参照スペクトル(破線) と膜厚 12 $\mu \mathrm{m}$ のインク薄膜(水分含有量 $20 \%$ ) 試料を透過したテラへ ルツ電磁波のスペクトルを示している。Fig. 12中の鋭い ディップは水蒸気による吸収線である。解析を行うに際 し, 水蒸気吸収が少なく, スペクトル上でテラヘルツ強 度が最大となる0.6〜1.05 THzを抽出した. Fig. 13に膜厚と 水分含有量を変えて測定した透過スペクトルを示す。ス ペクトルの干渉縞は膜を挟んでいる石英板によるテラへ ルツ電磁波の干渉であり，この干渉縞は石英板をくさび 形にすることにより取り除くことが可能である. Fig. 13 (a) は水分含有量を0\%に固定し, 膜厚を变化させた結果で ある.膜厚が厚くなるに従って吸収が増していく様子が わかる. また，この吸収には周波数依存性があり，膜厚 が厚い試料ほど高周波での吸収が大きくなることがわか る. Fig. 13 (b) は膜厚を $12 \mu \mathrm{m}$ に固定し, 水分含有量を0〜 $20 \%$ \%で変化させたスペクトルである.Fig. 13 (a) と同 様，水分含有量が多くなるに従って吸収は増大している が，こちらには周波数に依存した吸収は観測されていな い。つまり, 膜厚に関する情報は周波数依存性を持つ吸 収に，水分含有量に関する情報は周波数依存性を持たな い吸収に反映されることになる。 Fig. 12中の実線は最小二 乗法を用いてフィッティングを行った結果である. 周波 数に依存する吸収と依存しない吸収が良く再現されてい る。これらの結果をまとめたものがFig. 14である. Fig. 14 (a) は周波数依存性を持つ吸収 $\left.\alpha_{\omega}, （ \mathrm{~b}\right)$ は周波数依存性を 持たない吸収 $\alpha_{0}$ をそれぞれ示している， $\alpha_{\omega} ， \alpha_{0}$ ともに膜

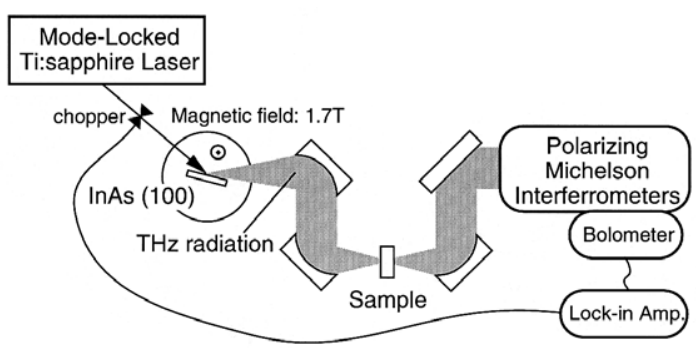

Fig. 11 Experimental setup for simultaneously measuring thickness and water content of thin black ink films. The magnetic field direction is from the back to the surface. 


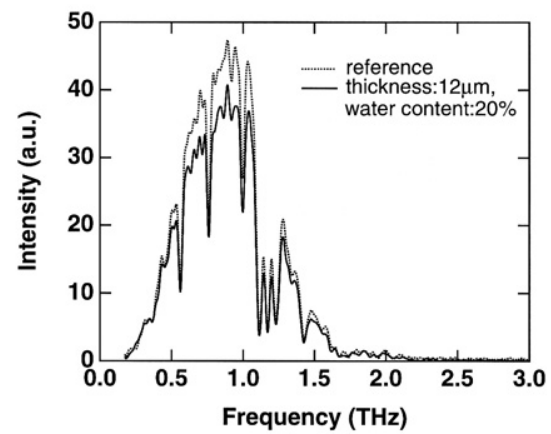

Fig. 12 Typical spectra for reference (dashed curve) and thin black ink film with $12-\mu \mathrm{m}$ thickness and $20-\%$ water content (solid curve).

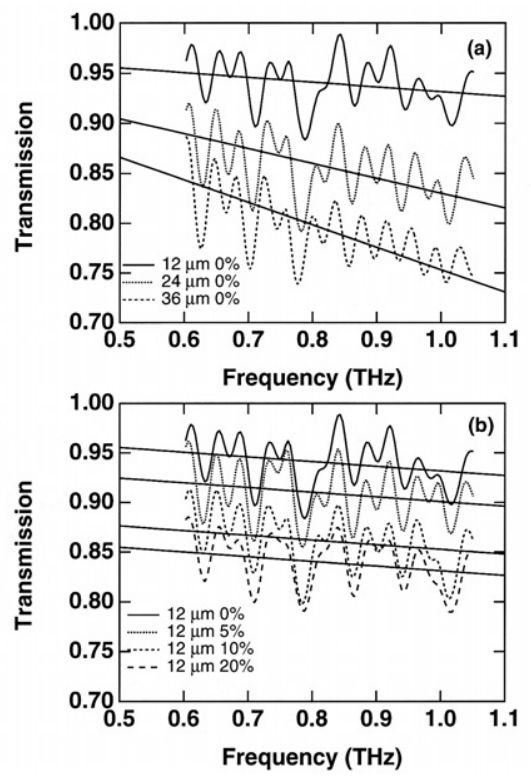

Fig. 13 The transmission spectra for various thin black ink films. (a) 12-, 24- and 36- $\mu \mathrm{m}$ thickness, no water content films; (b) 12- $\mu$ m thickness, 0-, 5-, 10-, 20$\%$ water content films.

厚及び水分含有量が増すにつれて大きくなっている．実 験結果はFig. 14 (a)，（b）に示した実線で再現される。実 線は以下のような式で与えられる。

$$
\alpha_{\omega}=0.0061 \times \mathrm{m} \text {, }
$$$$
\alpha_{0}=0.029+0.005 \times \mathrm{x} \text {, }
$$

ここでmは膜厚 $(\mu \mathrm{m}), \mathrm{x}$ は水分含有量 $(\%)$ である，従っ て，測定したスペクトルから $\alpha_{\omega}$ と $\alpha_{0}$ を算出することによ り膜厚 $\mathrm{m}$ と水分含有量 $\mathrm{x}$ の同時測定が可能となる。

以上のように，テラヘルツ電磁波を用いて，簡単な， 非接触のインク膜厚と水分含有量の同時測定を実現し た。この系統の測定は様々な分野において潜在的な要請 があると考えられるため, 今後の発展が期待される.

\section{4. 将来の展望}

今回紹介した磁場印加の手法は非常に簡便であり, 他 のシステムに比べて圧倒的に安価であるため, 新技術実 現の強力な道具立てとなる。テラヘルツ領域のイメージ
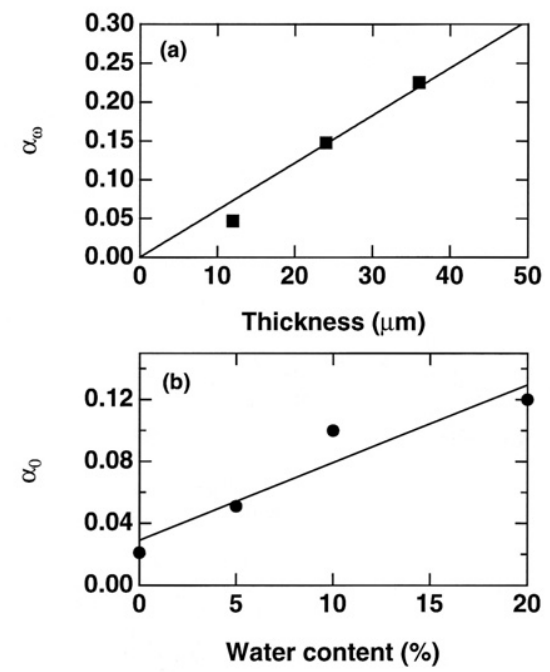

Fig. 14 Fitting parameters for transmission spectra. (a) Water content dependence of $\alpha_{\omega}$, (b) Thickness dependence of $\alpha_{0}$. The thickness and water content of thin black ink films are determined simultaneously from these results.

ングにおいても高強度テラヘルツ電磁波は必要不可欠で あり，医療応用や生体分子計測に用いられている。特に 医療応用では，エックス線とは異なり，人体に無害な高 透過性コヒーレント光源として世界中で広く研究が成さ れている。近い将来, 簡単な透過画像にはテラヘルッ電 磁波を用いることが当然になるような社会が実現するか も知れない。これらの技術は夢のテーマであった人にも 物にも優しいエックス線に代わる夢の光を創り出すこと に大きな力を発揮するものと考えられる。

\section{参考文献}

1) D. H. Auston: Appl. Phys. Lett. 45 (1984) 284

2) Q. Wu and X. -C. Zhang: Appl. Phys. Lett. 68 (1996) 1604.

3) N. Sarukura, H. Ohtake, S. Izumida, and Z. Liu: J. Appl. Phys. 84 (1998) 654.

4) H. Ohtake, S. Ono, M. Sakai, Z. Liu, T. Tsukamoto, and N. Sarukura: Appl. Phys. Lett. 76 (2000) 1398.

5) S. Ono, T. Tsukamoto, E. Kawahata, T. Yano, H. Ohtake, and N. Sarukura: Appl. Opt. 40 (2001) 1369.

6) X. -C. Zhang, Y. Jin, L. E. Kingsley, and M. Weiner: Appl. Phys. Lett. 62 (1993) 2477.

7) S. Izumida, Shingo Ono, Z. Liu, H Ohtake, and N. Sarukura: Appl. Phys. Lett. 75 (1999) 451.

8) C. Weiss, R. Wallenstein, and R. Beigang: Appl. Phys. Lett. 77 (2000) 4160.

9) H. Ohtake, S. Ono, Z. Liu, N. Sarukura, M. Ohta, K. Watanabe, and Y. Matsumoto: Jpn. J. Appl. Phys. 38 (1999) L1186.

10) S. Ono, T. Tsukamoto, M. Sakai, Z. Liu, H. Ohtake, N. Sarukura, S. Nishizawa, A. Nakanishi, and M. Yoshida: Rev. Sci. Instrum. 71 (2000) 554.

11) H. Ohtake, Y. Suzuki, N. Sarukura, S. Ono, T. Tsukamoto, A. Nakanishi, S. Nishizawa, M. L. Stock, M. Yoshida, and H. Endert: Jpn. J. Appl. Phys. 40 (2001) L1223.

12) for example, K. Tominaga, H. Ohtake, N. Sarukura, K. Saitow, H. Sasakawa, A. Tamura, I. Rubtsov, and K. Yoshihara: Advances in Multi-Photon Processes and Spectroscopy 14 (2001) 317.

13) for example, K. Saitow, H. Ohtake, N. Sarukura, and K. Nishikawa: Chem. Phys. Lett. 341 (2001) 86.

14) 長谷川 公平：電学論C, 108 (1988) 493.

15) H. Ohtake, Y. Suzuki, S. Ono, N. Sarukura, T. Hirosumi, and T. Okada: Jpn. J. Appl. Phys. 41 (2002) L475. 